\title{
The role of thaumatin II in cucumber resistance against Tetranychus urticae Koch: laboratory and greenhouse evaluation
}

\author{
MAŁGORZATA KIEŁKIEWICZ1, MAŁGORZATA CZARNECKA ${ }^{1}$, SŁAWOMIR ORZECHOWSKI² \\ and MARIA SZWACKA ${ }^{3}$ \\ ${ }^{1}$ Department of Applied Entomology, Faculty of Horticulture and Landscape Architecture, \\ e-mail: malgorzata_kielkiewicz@sggw.pl \\ ${ }^{2}$ Department of Biochemistry, Faculty of Agriculture and Biology; ${ }^{3}$ Department of Plant Genetics, \\ Breeding, and Biotechnology, Faculty of Horticulture and Landscape Architecture, \\ Warsaw University of Life Sciences, PL-02-776 Warsaw, Nowoursynowska 159
}

(Received on 18 January 2008; Accepted on 2 October 2009)

\begin{abstract}
The role of thaumatin II in the resistance of transgenic cucumber plants of the T6 generation against the two-spotted spider mite (TSSM) (Tetranychus urticae C.L. Koch 1836, Acari: Tetranychidae) was determined in greenhouse experiments evaluating: (1) mite behaviour towards cucumber lines (T224 09, T212 01, T210 06) differing in the level of thaumatin II expression, (2) mite reproductive capacity, (3) mite colonisation ability, and (4) mite leaf damage. Additionally, using Western blot, the presence of thaumatin II in leaves of transgenic cucumber plants of the T6 generation was analysed before and after TSSM feeding. Even plants with a relatively high leaf thaumatin II level (T224 09 and T212 01) were equally well accepted by TSSM in a 'free-choice' test, which excludes thaumatin II as an important factor in the process of host plant acceptance. However, a reduced fecundity of mite females and a lower, than in the control, number of mites found in the period of permanent feeding on thaumatin-rich plants, indicate a putative role of thaumatin II in the plant-mite interactions. The lack of a clear relationship between the level of thaumatin II and plant resistance to TSSM may be a sign that thaumatin II is not a direct factor involved in antibiosis. In response to TSSM, the thaumatin II content decreases, increases, or remains unchanged in mite-infested leaves, which excludes thaumatin II as being directly involved in induced defence.
\end{abstract}

Keywords: two-spotted spider mite, Cucumis sativus, acceptance, induced response, mite colonisation, mite performance

\section{INTRODUCTION}

Improvement of nutritive and taste values of fruit and vegetables is one of the major objectives of modern plant breeding. The thaumatin II gene encodes a sweet protein and, when introduced to the genome of cucumber or tomato plants, it is responsible for the sweeter taste of fruit (SzwACKA et al. 2000, KosIERADZKA et al. 2001, Bartoszewski et al. 2003, Gajc - WolsKa et al. 2005). Thaumatin II represents the thaumatin-like (TL) proteins and belongs to the PR-5 family of pathogenesis-related 
(PR) proteins (VAN Loon et al. 1994). TL-proteins are often rapidly biosynthesised in plants in response to a range of abiotic factors (VAN LoON et al. 1994, VAN LoON 1997), pathogens (KoIwA et al. 1994, HeRNANDEZ et al. 2005, Yin et al. 2005), insects (Forslund et al. 2000, Voelckel et al. 2004, Zhu-Salzman et al. 2004), and nematodes (SANZ - Alferez \& DiAZ - Rullo 2007).

Earlier reports presented the protective role of thaumatin II in transgenic cucumber plants of the T4 generation against some common cucumber pests, including TSSM in open field conditions (KIEŁKIEwICZ et al. 2006, 2009). Surprisingly, further field observations, focusing on plant colonisation and development of the mite population on cucumber plants of subsequent generations (T5, T6, T7) did not confirm such unequivocal results (KIEEKIEWICZ, unpublished).

Studies carried out during recent years have shown that the insertion of the thaumatin II gene in cucumber plants not only results in an improved taste of fruit (Szwacka et al. 2000, KosieradZka et al. 2001, Gajc-Wolska et al. 2005) but also, to some extent, moderates the metabolism of transgenic plants (TAGASHIRA et al. 2005, YIN et al. 2005 and references therein, KIEŁKIEWICZ et al. 2006, 2009, KIEtKIEWICZ et al. 2008a, b). Specifically, as a result of transgenesis, leaf and fruit tissues of some cucumber lines expressing the thaumatin II gene differ in the mutual proportion of secondary (defence-related) to primary (growth-sustaining) metabolites (KIEŁKIEWICZ et al. 2008a). Recently, it has been documented that the transformation of cucumber plants with the thaumatin II gene resulted in an increased abundance of some polypeptides, both in mature and young leaves (KIEEKIEWICZ et al. 2008b). Furthermore, the assessment of peroxidase (POX) activity showed that the transformation suppressed the involvement of POX isoforms in defence response of transgenic cucumber plants against TSSM (KIEŁKIEWICZ et al. 2008b).

Since economic injuries due to TSSM infestation of commercially available cucumber cultivars may reach a high level in the season, thus affecting the market value of cucumber fruit (Hussey \& Scopes 1985, PARK \& Lee 2007), this study focused primarily on the assessment of resistance of transgenic cucumber plants of the T6 generation (varying in expression of the thaumatin II gene) to TSSM. The resistance of nontransgenic (control) and transformed plants was compared under greenhouse conditions based on: (1) mite behaviour towards cucumber lines, (2) mite reproductive capacity, (3) mite colonisation ability, and (4) mite leaf damage. In addition, using Western blot analysis, the presence of thaumatin II in leaves of thaumatin-rich plants was assessed, as it may be relevant to the performance of TSSM.

\section{MATERIAL AND METHODS}

\section{Plants}

In this study we used 3 cucumber lines (T210 06, T212 01, T224 09) of the T6 generation, originating from 3 independent events and containing in the genome the p35S:: thaumatin II cDNA construct (SzWACKA et al. 2002). The transgenic cucumber lines varied in the level of thaumatin II: leaves of lines T224 09 and T212 01 showed a relatively high amount of the sweet protein, whereas in leaves of the T210 06 line there was a relatively low level (SzWACKa et al. 2000, Szwacka et al. 2002, KietKIEWICZ 
et al. 2006, 2009). Plants of near-isogenic, non-thaumatin II line Borszczagowski (line B) constituted the control. Seeds were sowed on 24 April 2006. Three-week-old seedlings were transplanted into peat substrate. Plants were grown in pots of $16 \mathrm{~cm}$ in diameter, in a greenhouse under natural light and photoperiod.

\section{Pest mite}

The population of TSSM was reared continuously on bean (Phaseolus vulgaris L.) plants under long-day conditions (day $16 \mathrm{~h}, 24^{\circ} \mathrm{C}$; night $8 \mathrm{~h}, 18^{\circ} \mathrm{C}$ ).

\section{Mite-preference bioassay}

The 'free-choice' preference tests used both for phytophagous insects and spider mites proved their value in determining the level of plant antixenosis to pests (DĄBROWSKi 1988, Sмiтh 2005). To assess the suitability of cucumber plants differing in the level of thaumatin II for TSSM, the 'free-choice' test was conducted, using 4-week-old plants. The experiment started on 22 May 2006. Four plants, i.e. one of each line (B, T210 06, T212 01, T224 09), were arranged around an arena (Fig. 1). The $3^{\text {rd }}$ fully-developed leaves of each plant were joined with each other and with the arena, on which we detached bean leaves infested with a large number of TSSM individuals. After 36 hours, cucumber plants in each group were checked for the number of mobile stages of TSSM. Six replicates were performed (each being a group of 4 plants).

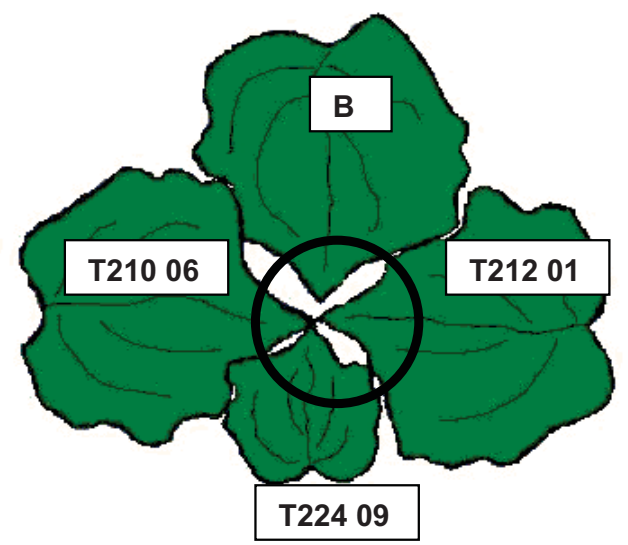

Fig. 1. The scheme of the 'free-choice' acceptance test. The scheme attains the correct proportion with respect to the $3^{\text {rd }}$ leaf inhabited within $36 \mathrm{~h}$, by mites moving from infested bean leaves placed in the arena's centre (circle)

\section{Mite reproductive capacity and mite colonisation ability}

To evaluate the effect of thaumatin II on mite reproductive capacity and colonisation ability, TSSM individuals were allowed to feed and spread freely within each cucumber plant of the examined lines for the next 7 days. After this time the number of TSSM eggs and mobile stages were recorded for every leaf of each plant by using 
a stereomicroscope (Olympus SZH10). Six replicates were performed (each being a group of 4 plant genotypes).

\section{Western blot}

Ten young females of TSSM were transferred from bean plants to the $5^{\text {th }}$ leaf on the main stem of 6-week-old cucumber plants growing in the greenhouse. After 7 days of feeding, the leaf samples were collected from noninfested and infested plants of lines B, T210 06, T212 01, and T224 09. The total soluble proteins from leaf samples were extracted with a mixture of $50 \mathrm{mM}$ Tris buffer, $\mathrm{pH} 8.0,1 \mathrm{mM}$ ethylene diaminetetraacetic acid (EDTA) pH 8.0, $15 \mathrm{mM} \beta$-mercaptoethanol, 1\% phenylmethylsulphonyl fluoride (PMSF), and then the homogenates were centrifuged (15 $000 \mathrm{rpm}$ for $10 \mathrm{~min}$ ) at $4^{\circ} \mathrm{C}$. Total protein was determined according to BRADFORD (1976), by using bovine albumin as a standard, and $20 \mu \mathrm{g}$ of protein was loaded onto each lane of $12 \%$ polyacrylamide gel. The proteins were transferred to a ImmunBlot ${ }^{\circledR}$ polyvinylidene fluoride (PVDF) membrane (Bio-Rad, USA). When the transfer had been completed, membranes were stained with $0.1 \%$ Ponceau in $5 \%$ acetic acid. Thaumatin II from Thaumatococcus danielli (Benth) (Sigma, St. Louis, MO, USA) was used as a positive control, and the Prestained Protein Molecular Weight Marker (Fermentas, Life Sciences, USA) was used as a molecular mass marker. The membranes were blocked for $1 \mathrm{~h}$ in $3 \%$ fat-free milk in tris-buffered saline (TBS). After washing with TBS, the membranes were incubated with polyclonal antibodies (rabbit anti-thaumatin) diluted 1:5000 (v/v) for $60 \mathrm{~min}$. To incubate the membranes at room temperature for $60 \mathrm{~min}$ with secondary antibodies, an anti-rabbit IgG-alkaline phosphatase (Sigma, St. Louis, MO, USA) (diluted 1:15 000, v/v) was used. To develop blots, the membranes were thereafter washed, and Western blot detection reagents (acid phosphatase, 5-bromo-4-chloro-3-indolyl phosphate/nitro blue tetrazolium, BCIP/NBT) were used. Briefly, the membranes were incubated in AP buffer (100 $\mathrm{mM}$ Tris, $100 \mathrm{mM} \mathrm{NaCl}, 5 \mathrm{mM} \mathrm{MgCl}_{2}$, and $\mathrm{HCl}$ to adjust to $\mathrm{pH} \mathrm{9.5),} \mathrm{contain-}$ ing $33 \mu \mathrm{l}$ of BCIP and $60 \mu \mathrm{l}$ of NBT in each $10 \mathrm{ml}$ of the buffer. After 20-25 min of incubation, the membrane was rinsed with distilled water and dried.

\section{Statistical analysis}

The results were statistically analysed with one-way or two-way analysis of variance (ANOVA). Differences between the means were tested with the Tukey HSD or a nonparametric, Kruskal-Wallis test, at $P=0.05$.

\section{RESULTS AND DISCUSSION}

\section{Mite preference towards cucumber lines}

In a 'free-choice' test performed in this study, the number of TSSM individuals located on plants of the T224 09 line was about 30\% lower than on a non-thaumatin (control) line B and thaumatin lines T210 06 and T212 01 (Fig. 2). As the number of TSSM mobile stages did not statistically differ between transgenic and nontransgenic plants $\left(F_{3,20}=0.49 ; P=0.69\right)$, it can be inferred that a relatively high thaumatin II level was not the factor restraining the mites within the probing and initial feeding 


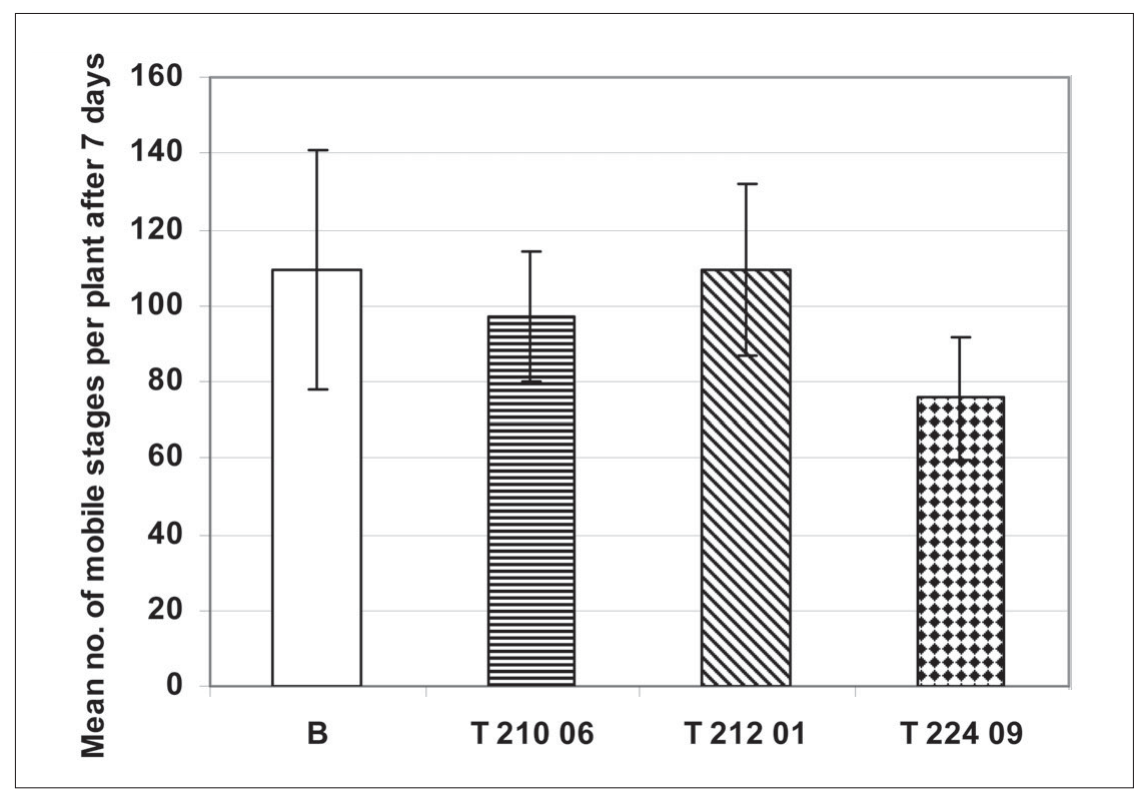

Fig. 2. The number of TSSM mobile stages (mean \pm SD) on the $3^{\text {rd }}$ leaf of cucumber line B (control) plants and on the $3^{\text {rd }}$ leaf of transgenic plants of T210 06, T212 01, T224 09 lines ('free-choice' test, $36 \mathrm{~h}$ of colonisation). Error bars denote standard deviation

period. Earlier studies on the cucumber plant-TSSM interactions show a different preference of mites toward various commercial cucumber cultivars (TомсZYк 1989). According to some other studies, choosing the most attractive host plant from among numerous species/cultivars/lines has a great impact on the further reproductive success (DAвRowski 1988, TomcZYк 1989, KIEeKIEwicz 1996, 2003). On the other hand, many cultivated plants (apple trees for example), which are highly acceptable at the stage of initial feeding of T. viennensis and T. urticae, did not provide the mite with suitable conditions for successful reproduction (SKORUPSKA 2003). In conclusion, due to the fact that there was no significant decrease in the attractiveness of cucumber plants of lines T224 09 and T212 01 (which had a relatively high thaumatin II level in leaves) to TSSM, thaumatin II is excluded as being involved in the process of host plant acceptance by TSSM.

\section{Mite reproductive capacity}

The present study showed that, compared with the control plants (line B), the density of TSSM mobile stages was significantly lowered $(H=13.34 ; P=0.004)$ on plants of lines T210 06, T 21201 and T224 09: by 39\%, 49\%, and 58\%, respectively (Fig. 3). The oviposition rate of females feeding on plants of T210 06, T212 01 and T224 09 lines was lowered $\left(F_{3,20}=8.51 ; P=0.0008\right)$, by $62 \%, 55 \%$, and $62 \%$, respectively, in comparison with the control line B (Fig. 3). A limited reproductive 


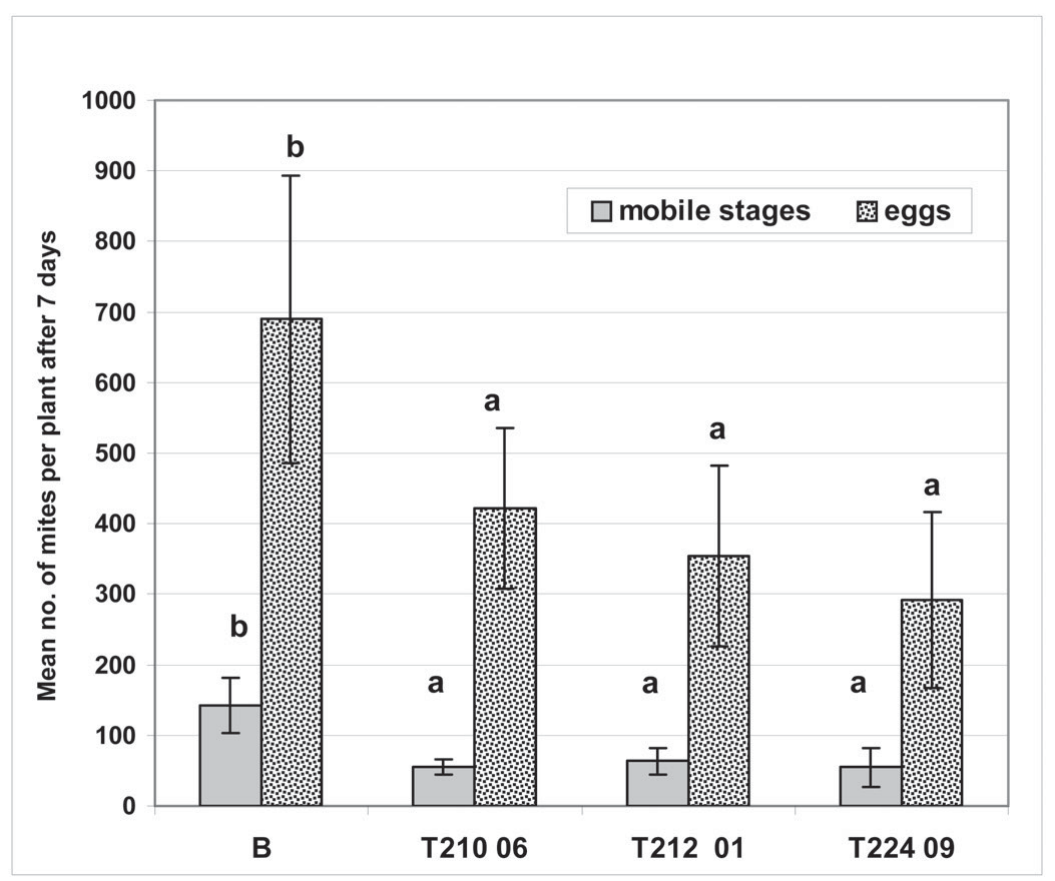

Fig. 3. The number of TSSM eggs and mobile stages (mean \pm SD) on cucumber line B (control) plants and transgenic plants of T210 06, T212 01, T224 09 lines on the $8^{\text {th }}$ day of the experiment. Different letters above error bars indicate significant differences (Kruskal-Wallis test for mobile stages and Tukey HSD test for eggs, $P=0.05$ ). Error bars denote standard deviation

capacity of TSSM on cucumber plants of the T6 generation, expressing thaumatin II, suggests the antibiotic effect of transgenic plants on pest biology. However, in relation to the control, the reduction of mite reproductive capacity was quite similar on examined transgenic plants, regardless of the thaumatin II level. Therefore, the thaumatin II content seems unlikely to contribute to the cucumber plants' antibiotic effect on TSSM. Unintended changes in the metabolic profile of transgenic plants may therefore be suspected to affect their resistance to phytophagous mites, as it was suggested earlier by other authors (TAGASHIRA et al. 2005, Yin et al. 2005, KIEEKIEWICZ et al. 2008a, b).

It is known that host-plant attractiveness to herbivores is strongly moderated by the content of primary compounds directly involved in plant growth and development as well as by secondary compounds of antixenotic or antibiotic nature: phenolics, terpenoids, glycosides, alkaloids, lignin, etc. (DĄBROWski 1988, BernaYs \& CHAPMAN 1994, Sмiтн 2005). Recent studies have shown that, compared to the control line B, the ratio of phenolics to total proteins and reducing sugars was elevated in leaves of transgenic lines T210 06, T212 01, T224 09 by $8 \%, 24 \%$, and $18 \%$, respectively (KIEtKIEWICZ et al. 2008a). It has also been emphasised that an increase in the ratio of phenolics to lignin in leaves of all transformed cucumbers of the T5 generation, com- 
pared to the control, implies an imbalance between soluble and insoluble secondary compounds. Therefore, the variation in leaf quality of transformed cucumber lines of the T6 generation, as a result of the thaumatin II gene insertion, could potentially affect mite reproductive capacity.

\section{Mite colonisation ability}

The distribution of TSSM mobile stages varied between control plants (line B) and transgenic lines (T210 06, T212 01, T224 09) investigated 7 days after the plants had been inhabited by mites (Tables 1 and 2). Statistically significant differences

Table 1. The distribution of TSSM mobile stages on leaves of the main shoot in nontransgenic and transgenic cucumber lines. Different letters within columns indicate significant differences (Kruskal-Wallis test, $P=0.05$ )

\begin{tabular}{lllll}
\hline $\begin{array}{l}\text { Number of consecutive leaf on } \\
\text { stem* }\end{array}$ & \multicolumn{1}{c}{ B } & T210 06 & T212 01 & T224 09 \\
\hline 3 (bottom) & $476.3 \mathrm{c}$ & $179.2 \mathrm{~d}$ & $243.2 \mathrm{c}$ & $196.3 \mathrm{~b}$ \\
4 & $274.3 \mathrm{~b}$ & $76.7 \mathrm{c}$ & $84.5 \mathrm{~b}$ & $40.0 \mathrm{a}$ \\
5 & $51.3 \mathrm{a}$ & $33.2 \mathrm{~b}$ & $29.3 \mathrm{ab}$ & $22.7 \mathrm{a}$ \\
6 & $24.6 \mathrm{a}$ & $24.5 \mathrm{ab}$ & $15.8 \mathrm{a}$ & $7.3 \mathrm{a}$ \\
7 & $19.5 \mathrm{a}$ & $9.3 \mathrm{a}$ & $8.7 \mathrm{a}$ & $6.0 \mathrm{a}$ \\
8 (upper) & $5.7 \mathrm{a}$ & $4.3 \mathrm{a}$ & $2.0 \mathrm{a}$ & \\
\hline \multirow{2}{*}{ Test results } & $H=27.7942$ & $H=31.5102$ & $H=29.0606$ & $H=20.8185$ \\
& $P=0.0001$ & $P=0.0000$ & $P=0.0000$ & $P=0.0003$ \\
\hline
\end{tabular}

*starting from the $3^{\text {rd }}$ one, which adjoined the arena

Table 2. The distribution of TSSM eggs on leaves of the main shoot in nontransgenic and transgenic cucumber lines. Different letters within columns indicate significant differences (Kruskal-Wallis test, $P=0.05$ )

\begin{tabular}{lllll}
\hline $\begin{array}{l}\text { Number of consecutive leaf } \\
\text { on stem* }\end{array}$ & \multicolumn{1}{c}{$\mathrm{B}$} & T210 06 & T212 01 & T224 09 \\
\hline 3 (bottom) & $1287.0 \mathrm{c}$ & $1233.5 \mathrm{~d}$ & $789.3 \mathrm{~b}$ & $850.3 \mathrm{~b}$ \\
4 & $1237.5 \mathrm{c}$ & $694.8 \mathrm{c}$ & $815.3 \mathrm{~b}$ & $386.3 \mathrm{a}$ \\
5 & $871.0 \mathrm{bc}$ & $379.7 \mathrm{~b}$ & $353.3 \mathrm{a}$ & $139.7 \mathrm{a}$ \\
6 & $593.3 \mathrm{ab}$ & $128.2 \mathrm{a}$ & $115.2 \mathrm{a}$ & $60.2 \mathrm{a}$ \\
7 & $126.8 \mathrm{a}$ & $71.2 \mathrm{a}$ & $49.3 \mathrm{a}$ & $22.0 \mathrm{a}$ \\
8 (upper) & $24.0 \mathrm{a}$ & $25.2 \mathrm{a}$ & $6.0 \mathrm{a}$ & \\
\hline \multirow{2}{*}{ Test results } & $H=27.2478$ & $H=31.6377$ & $H=30.5846$ & $H=23.3019$ \\
& $P=0.0000$ & $P=0.0000$ & $P=0.0000$ & $P=0.0001$ \\
\hline
\end{tabular}

*starting from the $3^{\text {rd }}$ one, which adjoined the arena 
Table 3. A comparison of the number of TSSM mobile stages from 3 consecutive leaves in nontransgenic and transgenic cucumber lines. Different letters within rows indicate significant differences (Tukey HSD or Kruskal-Wallis test, $P=0.05$ )

\begin{tabular}{lrrrrr}
\hline $\begin{array}{l}\text { Number of consecutive leaf } \\
\text { on stem* }\end{array}$ & B & T210 06 & T212 01 & T224 09 & Test results \\
\hline 3 (bottom) & $476.3 \mathrm{~b}$ & $179.2 \mathrm{a}$ & $243.2 \mathrm{a}$ & $196.3 \mathrm{a}$ & $\begin{array}{l}F_{3,20}=5.54 \\
P=0.0062\end{array}$ \\
\hline 4 & $274.3 \mathrm{~b}$ & $76.7 \mathrm{a}$ & $84.5 \mathrm{a}$ & $40.0 \mathrm{a}$ & $\begin{array}{l}H=14.548 \\
P=0.0023\end{array}$ \\
\hline 5 (upper) & 51.3 & 33.2 & 29.3 & 22.7 & $\begin{array}{l}H=3.2195 \\
P=0.3591\end{array}$ \\
\hline
\end{tabular}

*starting from the $3^{\text {rd }}$ one, which adjoined the arena

Table 4. A comparison of the number of TSSM eggs from 3 consecutive leaves in nontransgenic and transgenic cucumber lines. Different letters in rows indicate significant differences (Tukey HSD or Kruskal-Wallis test, $P=0.05$ )

\begin{tabular}{lrrrrr}
\hline $\begin{array}{l}\text { Number of consecutive } \\
\text { leaf on stem* }\end{array}$ & B & T210 06 & T212 01 & T224 09 & Test results \\
\hline 3 (bottom) & 1287.0 & 1233.5 & 789.3 & 850.3 & $\begin{array}{l}H=4.8067 \\
P=0.1865\end{array}$ \\
\hline 4 & 1237.5 & 694.8 & 815.3 & 386.3 & $\begin{array}{l}F_{3,20}=2.45 \\
P=0.093\end{array}$ \\
\hline 5 (upper) & $871.0 \mathrm{~b}$ & $379.7 \mathrm{a}$ & $353.3 \mathrm{a}$ & $139.7 \mathrm{a}$ & $\begin{array}{l}F_{3,20}=14.3 \\
P=0.0000\end{array}$ \\
\hline
\end{tabular}

*starting from the $3^{\text {rd }}$ one adjoining the arena

were also revealed when comparing the density of mobile stages of TSSM (Table 3) and eggs (Table 4) on spatially corresponding leaves. TSSM mobile stages and eggs (Tables 1 and 2) were significantly more numerous (except for lines B and T212 01) on the leaves that were directly adjacent to the arena ( $3^{\text {rd }}$ from the shoot base), whereas leaves located above the one that contacted the arena, hosted 2-4-fold fewer mobile stages (Table 1). Similar behaviour of spider mites had already been observed on other vegetable plants (Hussey \& Scopes 1985, KieŁKIEwicz 1996). According to SABELIS (1985), adult individuals of various spider mite species usually show a vertical rather than horizontal course of movement. It is known that the interaction 
of TSSM with its host plant Cucumis sativus L. resulted in the increased synthesis of cucurbitacins, which reduced mite population growth (AgRAWAL et al. 2002). Thus we cannot exclude the participation of these terpenoids in the mite-colonisation process of thaumatin-cucumber plants.

\section{Western blot}

Western blot revealed a differentiated expression of thaumatin II in leaves of the cucumber line of the subsequent T6 generation (Fig. 4). There was a similar expression of sweet-tasting protein in control leaves of lines T224 09 and T212 01, and it was stronger than in control leaves of line T210 06. Our results are consistent with earlier reports concerning thaumatin II expression at the translational level in leaves of transgenic cucumber plants of earlier generations (T4 and T5), in which the level of thaumatin II was the highest for line T224 09, slightly lower for line T212 01, and detected in a trace amount in line T210 06 (SzWACKA et al. 2000, KIEŁKIEWICZ et al. 2006, 2008a, b, 2009). Since no marked relationship between the level of leaf thaumatin II in plants of the T6 generation and transgenic plant susceptibility to TSSM (Fig. 1, Table 3 and 4) was found, this protein seems irrelevant to the mechanisms of the constitutive resistance.

Our Western blots show that in response to TSSM feeding, the thaumatin II level in mite-injured leaves undergoes changes differentially, depending on the cucumber line: it is decreased slightly in the mite-injured leaf of line T212 01, increased slightly in line T224 09, and is stable in line T210 06 (Fig. 4). These results apparently exclude thaumatin II as being involved in the induced defence response to TSSM. Results of a previous study (KIEŁKIEWICZ et al. 2008a) on the role of thaumatin II in mite-damaged leaves of transgenic line T212 01 of the earlier T5 generation, brought similar conclusions. However, KIEŁKIEwICZ et al. (2008a) examined the $8^{\text {th }}$ leaf of 4week-old plants in response to TSSM infestation (10 females per 7 days), whereas in this study the $5^{\text {th }}$ leaf of 6 -week-old plants in response to the same initial number of mites was evaluated.

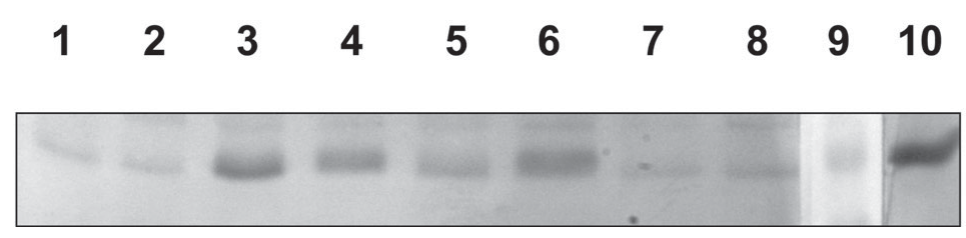

Fig. 4. Western blot analysis of total protein samples of cucumber leaves. Lane $1=$ infested leaf of line T210 06; line 2 = noninfested leaf of line T210 06; lane 3 = infested leaf of line T224 09; lane $4=$ noninfested leaf of line T224 09; lane $5=$ infested leaf of line T212 01; line $6=$ noninfested leaf of line T212 01; lane 7 = infested leaf of line B; lane $8=$ noninfested leaf of line B; line $9=$ molecular mass marker (Fermentas life Sciences, USA); lane $10=$ positive control, thaumatin (22 $\mathrm{kDa}$ ) from T. daniellii (Sigma, USA); $20 \mu \mathrm{g}$ of total soluble protein were loaded in each lane, separated by $12 \%$ PAGE, and blotted. The membrane was probed with anti-thaumatin II antibody 


\section{TSSM leaf damage}

Some minor, single necroses appeared on the upper surface of leaf blades of examined cucumber lines already several hours after colonisation by TSSM. Fig. 5 presents the density of necroses after 7 days of mite feeding. Larger and more abundant necroses found on leaves of lines B and T210 06 than on leaves of lines T212 01 and T224 09 suggest that the food taken up from these leaves better satisfied the nutritional requirements of TSSM, allowing the pest mite to stay longer in one place.


Fig. 5. TSSM damage to nontransgenic control cucumber plants (line B) and transgenic plants (line T210 06, T212 01 and T224 09) after 7 days of mite feeding

\section{CONCLUDING REMARKS}

In this study we showed differentiation in the abundance of thaumatin II in T224 09, T212 01 and T210 06 lines of the T6 generation, similar to that found in plants of earlier generations (T5 and T4) of these lines. The transgenic cucumbers differentially affected the TSSM reproductive potential. However, thaumatin II does not seem to be the direct determinant in the process of acceptance or antibiosis of transgenic plants to TSSM. In response to TSSM feeding, the induction of thaumatin 
II was not uniform in mite-damaged leaves of transgenic lines, so the unintended changes in the metabolism of transformed cucumbers of the T6 generation expressing thaumatin II could influence the mites' preference and reproductive capacity.

Acknowledgements: This research was supported in part by the Polish Ministry of Science and Higher Education (grant no. 2P06R01729).

\section{REFERENCES}

Agrawal A. A., Janssen A., Bruin J., Posthumus M. A., Sabelis M. W. 2002. An ecological cost of plant defence: attractiveness of bitter cucumber plants to natural enemies of herbivores. Ecol. Lett. 5: 377-385.

Bartoszewski G., Niedziela A., Szwacka M., Niemrowicz-Szczytt K. 2003. Modification of tomato taste in transgenic plants carrying a thaumatin gene from Thaumatococcus daniellii Benth. Plant Breed. 122: 347-351.

Bernays E. A., Chapman R. F. 1994. Host-plant selection by phytophagous insects. 305 pp., Chapman \& Hall, New York NY.

BRADFORD M.-M. 1976. A rapid and sensitive method for the quantification of microgram quantities of protein utilizing the principle of proteindye-binding. Anal. Biochem. 72: 248 - 254 .

DĄBRowSKI Z. T. 1988. Odporność roślin uprawnych na roztocze (Acarina) [Resistance of crop plants to acarid mites]. In: Podstawy odporności roślin na szkodniki [Resistance of plants to pests], pp. 51-65, PWRiL, Warszawa.

Forslund K., Pettersson J., Bryngelsson T., Jonsson L. 2000. Aphid infestation induces PR-proteins differently in barley susceptible or resistant to the bird-cherry-oat aphid (Rhapalosiphum padi). Physiol. Plant. 110: 496-502.

Gajc-Wolska J., Szwacka M., Malepszy S. 2005. The evaluation of fruit quality (Cucumis sativus L.) of transgenic lines with thaumatin gene. Folia Hort. 17/2: 23-28.

Hernandez I., Portieles R., Chacon O., Borras-Hidalgo O. 2005. Proteins and peptides for the control of phytopathogenic fungi. Biotecnol. Apl. 22: 256-260.

Hussey N. W., Scopes N. E. A. 1985. Greenhouse vegetables. In: Spider Mites, Their Biology, Natural Enemies and Control (Helle W., SAbelis M. W., Eds), vol 1B, pp. 285-296, Elsevier, Amsterdam.

KIEŁKIEWICZ M. 1996. Dispersal of Tetranychus cinnabarinus on various tomato cultivars. Entomol. Exp. Appl. 80: 254-257.

KIEŁKIEWICZ M. 2003. Strategie obronne roślin pomidorów (Lycopersicon esculentum Mill.) wobec przedziorka szklarniowca (Tetranychus cinnabarinus Boisduval, Acari: Tetranychidae) [Defensive strategies of greenhouse tomato (Lycopersicon esculentum Mill.) plants against the carmine spider mite (Tetranychus cinnabarinus Boisd., Acari: Tetranychidae) infestation. Rozprawy Naukowe i Monografie [Treatises and Monographs]., 140 pp., SGGW, Warszawa [Publications of Warsaw Agricultural University, Warsaw].

Kiękiewicz M., Gajc-Wolska J., Szwacka M., Maleszy S. 2006. Genetically modified cucumbers with thaumatin II gene expression and their acceptance by pests Advances of Agricultural Science Problem Issues [Zeszyty Problemowe Postępów Nauk Rolniczych]. 509: 395-404.

Kiękiewicz M., Gajc-Wolska J., Szwacka M., Maleszy M. 2008a. Changes in biochemistry of cucumber carrying the thaumatin II gene: relevance to herbivores. IOBC wprs Bull. 33: 79-84.

Kiefkiewicz M., Gajc-Wolska J., Szwacka M., Maleszy S. 2009. Impact of transgenic cucumbers expressing the thaumatin II gene on the occurrence of arthropod fauna. In: Breeding for inducible resistance against pests and diseases., Proceedings of the meeting of IOBC/WPRS Work- 
ing Group "Breeding for Plant Resistance to Pest and Diseases" at Heraklio, Crete, 27-29 April, 2006. IOBC wprs Bull. 44: 149-153.

KietKiewicz M., MiazeK A., Szwacka M. 2008b. Local and systemic responses induced by Tetranychus urticae (Acari: Prostigmata: Tetranychidae) feeding in cucumber plants transformed with thaumatin II gene. In: Integrative Acarology. Proceedings of the $6^{\text {th }}$ Congress of the European Association of Acarologists (Bertrand M., Kreiter S., McCoy K. D., Migeon A., Navajas M., Tixier M-S. L., Vial L., Eds), pp. 472-477, Creative Commons-By-NC-ND (http://creativecommons.org/licenses/by-nc-nd/2.0/fr).

Koiwa H., Sato F., Yamada Y. 1994. Characterization of accumulation of tobacco PR-5 proteins by IEF-immuno-blot analysis. Plant Cell Physiol. 35: 821-827.

Kosieradzka I., Sawosz E., Pastuszewska B., Szwacka M., Malepszy S., Bielecki W., Czuminska K. 2001. The effect of feeding diets with genetically modified cucumbers on the growth and health status of rats. J. Animal Sci. 10: 7-12.

PARK Y. L., LeE J. H. 2007. Seasonal dynamics of economic injury levels for Tetranychus urticae Koch (Acari, Tetranychidae) on Cucumis sativus L. J. App. Entomol. 131(8): 588-592.

Sabelis M. W. 1985. Sampling Techniques. In: Spider Mites, Their Biology, Natural Enemies and Control (Helle W., Sabelis M. W., Eds), vol 1A, pp. 337-350, Elsevier, Amsterdam.

Sanz-Alférez S., Diaz-Rullo L. 2007. Plant defence responses by root-knot nematode interaction. Joint International Workshop on: 'PR-proteins' and 'induced resistance against pathogens and insects' at Doorn, The Netherlands, May 10-14, 2007. Abstract book. pp. 93.

SKORUPSKA A. 2003. Wpływ wybranych parcho-odpornych odmian jabłoni na bionomię dwóch gatunków przędziorków z rodzaju Tetranychus (Acarina, Tetranychidae) [Effect of scrab-resistant apple cultivars on the bionomics of two spider mite species of the genus Tetranychus (Acarina, Tetranychidae)] Rozprawy Naukowe IOR, No 11, 124 pp., Wydawnictwo IOR, Poznań.

Sмiтн C. M. 2005. Plant resistance to arthropods. Molecular and Conventional Approaches. 423 pp., Springer, Dordrecht, The Netherlands.

Szwacka M., Krzymowska M., KowalczyK M. E., Osuch A. 2000. Transgenic cucumber plants expressing the thaumatin gene. In: Progress in Biotechnology. Food Biotechnology (BIELECKI S., Tramper J., PolaK J., Eds), pp. 43-48, Elsevier Science B.V.

Szwacka M., Krzymowska M., Osuch A., Kowalczyk M. E., Malepszy S. 2002. Variable properties of transgenic cucumber plants containing the thaumatin II gene from Thaumatococcus daniellii. Acta Physiol. Plant. 24: 173-185.

Tagashira N., Pląder W., Filipecki M., Yin Z., Wiśniewska A., Gaj P., Szwacka M., Fiehn O., Hoshi Y., Kondo K., Malinowski R., Malepszy S. 2005. The metabolic profiles of transgenic cucumber lines vary with different chromosomal locations of the transgene. Cell Mol. Biol. Lett. 10: 697-710.

TомсZYк A. 1989. Physiological and biochemical responses of different host plants to infestation by spider mites (Acarina: Tetranychidae). 112 pp., Rozp. Monog. Wyd. SGGW, Warszawa.

VAN LoON L. C. 1997. Induced resistance in plants and the role of pathogenesis-related proteins. Eur. J. Plant Pathol. 103: 753-765.

Van Loon L. C., Pierpoint W. S., Boller T., Conejero V. 1994. Recommendations for naming plant pathogenesis-related proteins. Plant Mol. Biol. Report. 12: 245-264.

Voelckel C., Weisser W. W., Baldwin I. T. 2004. An analysis of plant-aphid interactions by different microarray hybridization strategies. Mol. Ecol. 13: 3187-3195.

Yin Z., Pląder W., Wiśniewska A., Szwacka M., Malepszy S. 2005. Transgenic cucumber - a current state. Folia Hort. 17: 73-90.

Zhu-Salzman K., Salzman R. A., Ahn J-E., Korwa H. 2004. Transcriptional regulation of sorghum defense determinants against a phloem-feeding aphid. Plant Physiol. 134: 420-431. 